\title{
Nutrient addition bioassays as indicators of nutrient limitation of phytoplankton in an eutrophic estuary
}

\author{
N. Holmboe*, H. S. Jensen, F. Ø. Andersen \\ Institute of Biology, University of Southern Denmark, Main Campus: Odense University, Campusvej 55 , \\ 5230 Odense, Denmark
}

\begin{abstract}
Seasonal variation in nutrient (nitrogen: N, and phosphorus: P) limitation of phytoplankton biomass growth was studied in the eutrophic estuary. Hjarbæk Fjord, Denmark, by use of 4 different types of bioassays. These were (1) long-term (2 d) nutrient addition bioassay, (2) long-term dilution bioassay, (3) short-term ( $2 \mathrm{~h}$ ) nutrient addition bioassay, and (4) short-term dilution bioassay. Types 1 and 2 were conducted as field incubations where increases in chlorophyll a (chl a) were used as a growth indicator, while Types 3 and 4 were laboratory incubations with measurement of ${ }^{14} \mathrm{C}$ uptake rates. Bioassays were compared with seasonal variations in carotenoid:chl a pigment ratio $(480: 665 \mathrm{~nm})$, nutrient pools (C:N:P ratios) in seston, concentrations of dissolved nutrients ( $N$ and $P$ ) in the water, and with the supply of nutrients ( $N$ and $P$ ) to the photic zone. P-limited growth dominated from May to August according to most bioassays, whereas $N$ limitation was only significant in the longterm nutrient addition bioassay in August. Estimates of nutrient loading to the photic zone included external input from freshwater and marine sources and nutrients regenerated from the sediment. The molar nutrient loading ratio ( $N$ : $)$ decreased through the summer from values of 290 and 110 for inorganic and total N:P, respectively, in April to a minimum value of 21 and 24 for inorganic and tatal N:P, respectively, in August. The minimum value coincided with the lowest inorganic N:P ratio in the surface water (3.5) and with a low ratio (15) of particulate N:P in the water column. Both short- and longterm nutrient addition bioassays corresponded well with the type of nutrient limitation that could be predicted from the seasonality in the N:P loading ratio and the inorganic N:P ratio in the surface water The dilution bioassays gave less clear results, but may still provide information on possible nutrient limitation in a situation where the external loadings of both $\mathrm{N}$ and $\mathrm{P}$ are decreased. The carotenoid:chl a ratio varied between 1.4 and 2.6 with the lowest values in April and October, where nutrient limitation was less evident, and with the highest value in August. The 480:665 ratio always decreased during long-term bioassays when nutrient addition stimulated growth, which implies that it may be indicative of $\mathrm{P}$ - as well as $\mathrm{N}$-limited growth.
\end{abstract}

KEY WORDS: Bioassay - Dilution-bioassay - Estuary · Nitrate Nutrient limitation - Phosphate Phytoplankton $\cdot 480: 665$ nm ratio

\section{INTRODUCTION}

Nutrient limitation of primary producers in aquatic environments has attracted much attention because increased supply of a limiting nutrient often leads to eutrophication and deterioration of the water quality (reviews in e.g. Hecky \& Kilham 1988, Fisher et al.

\footnotetext{
•E-mail:nikos@dou.dk
}

1995). In understanding and managing the water quality of lakes and coastal ecosystems it is therefore important to have good indicators of nutrient limitation and, especially, indicators which allow for an identification of the most limiting nutrient. The validity of such indicators is a matter of much debate (lately reviewed by Fisher et al. 1995). Another line of debate is whether nitrogen $(\mathrm{N})$ or phosphorus $(\mathrm{P})$ is the most limiting element in estuaries, coastal seas, and in lakes, (e.g. Hecky \& Kilham 1988). In freshwater systems phosphorus is 
generally believed to be the most important nutrient in regulating the primary production, while in marine systems nitrogen limitation prevails (Howarth 1988, Nixon et al. 1996). Whether there are fundamental differences in processes between freshwater and marine waters has been investigated, and one possible explanation, in a biogeochemical sense, is that $P$ is regenerated more efficiently from marine sediments than from freshwater sediments (Caraco et al. 1990). Howarth (1988) suggested that the difference rather should be explained by different nutrient loading ratios.

Calculations of $\mathrm{N}$ and $\mathrm{P}$ mass balances in Hjarbaek Fjord, Denmark (Jensen et al. 1994), indicated that this eutrophic estuary could provide a case of $P$ limitation during much of the growing season. It could also be expected from the mass balances that $P$ loading to the photic zone would decrease further in the years following 1992. In order to verify that $\mathrm{N}$ or $\mathrm{P}$ limitation in estuaries can be predicted from nutrient loadings and in order to provide a comparison of various indicators of $\mathrm{N}$ and $\mathrm{P}$ limitation we tested 4 different types of bioassays, and 4 'indicators' 6 times during the summer 1995 in the Hjarbæk Fjord estuary (Fig. 1, Stn 1). The survey was primarily based on nutrient addition bioassays (e.g. Maestrini et al. 1984, Schelske 1984, Granéli et al. 1986) using both short-term laboratory incubations and long-term field incubations. Since Hjarbæk

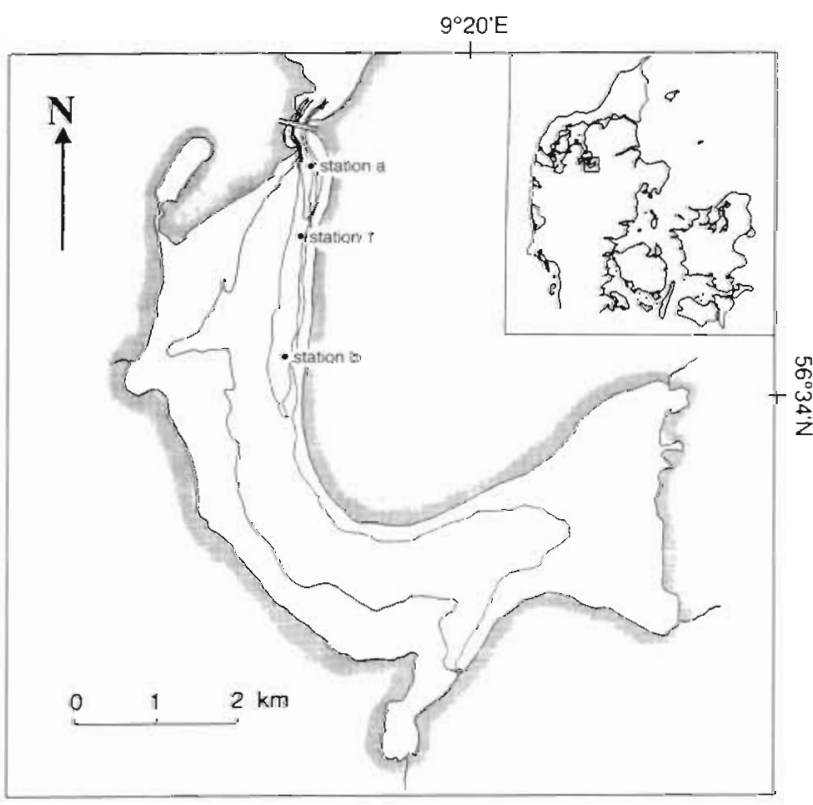

Fig. 1. Map of Hjarbæk Fjord. Denmark, and Stns $a_{\text {, }}$ b, and 1. Stn 1 was used for bioassay experiments. Stns a and b were used for measurements of nutrient release from the sediment. The fjord is separated from the outer fjord system by a sluice (north of Stn a). Inserted panel shows a map of Denmark with the location of the fjord. Interval between depth contours is $2 \mathrm{~m}$
Fjord occasionally experiences high levels of inorganic nutrients, we also tested dilution bioassays (sensu Paerl \& Bowles 1987) parallel to the ordinary nutrient addition bioassays, to show whether $\mathrm{N}$ or $\mathrm{P}$ could be potentially limiting in case of decreasing nutrient levels in the fjord. The carotenoid:chlorophyll a (chl a) ratio (480:665 $\mathrm{nm}$ absorption ratio) in field bioassays was tested as a supportive indicator for nutrient limitation. An increase in the 480:665 ratio could indicate nitrogen limitation according to Heath et al. (1990), where addition of nitrogen is expected to decrease the ratio in the case of $\mathrm{N}$ limitation. Finally the $\mathrm{C}: \mathrm{N}: \mathrm{P}$ ratio in particulate material was compared to Redfield's mean atomic ratio for marine phytoplankton, using this as an indicator of absence of $\mathrm{N}$ or $\mathrm{P}$ limitation (Redfield et al. 1963).

\section{STUDY SITE}

Hjarbæk Fjord, Denmark (56 $32^{\circ}$ N, $9^{\circ} 14^{\prime}$ E), covers an area of $24 \mathrm{~km}^{2}$ and has a watershed of about $1100 \mathrm{~km}^{2}$ (Fig. 1). Maximum and mean depths are 6.5 and $2 \mathrm{~m}$, respectively. The mean water residence time calculated from monthly freshwater input and seawater mixing is approximately 1 mo (Jensen et al. 1994). The estuary was isolated from marine water sources from 1966 until 1991 by a sluice. During this time the estuary turned into a freshwater system. Inflow of nutrient-rich water from the catchment caused eutrophication, and in the freshwater period phosphorus accumulated in the sediment. In 1992 the pool of ironbound $\mathrm{P}$ in the sediment was estimated to be 70 metric tons P (Jensen et al. 1994). To decrease the effects of eutrophication the sluice gate was opened in 1991, allowing more estuarine water with a lower nutrient content into the estuary and resulting in an average salinity of around 10 psu. Hjarbæk Fjord has a sill of $2 \mathrm{~m}$ depth at the marine boundary. This causes the water in the outer estuary near the sluice to stratify during the entire season, but the constant inflow of high density seawater forces the estuarine bottom water to mix with the outflowing low density surface water in the mid estuary, resulting in a residence time for water below the halocline of only $6 \mathrm{~d}$ (Jensen et al. 1994). Thus, nutrients released from the sediment are rapidly transported to the surface water. In 1992 the area-specific loading of $\mathrm{N}$ and $\mathrm{P}$ from freshwater sources was $75 \mathrm{~g} \mathrm{~N}$ $\mathrm{m}^{-2} \mathrm{yr}^{-1}$ and $1.7 \mathrm{~g} \mathrm{P} \mathrm{m}^{-2} \mathrm{yr}^{-1}$ (Jensen et al. 1994).

\section{MATERIALS AND METHODS}

The experiments were carried out during 1995, in the periods April 3-5, May 1-3, June 6-8, July 13-15, 
August 21-23 and October 2-4. These periods will be subsequently referred to by the name of the month. Freshwater inflow and nutrient loading from 4 major inlets were measured every 3 wk during the year while salinity and nutrient concentrations in inflowing marine water and outflowing estuarine water were measured every second week. The measurements, covering $85 \%$ of the total freshwater input, were performed by the County of Viborg (unpubl. data). The amount of inflowing seawater was calculated with time-steps of 1 mo on the basis of freshwater supply and differences in salinity in inflowing seawater and outflowing estuarine water. These waterbodies could be easily identified because of the sill and the sluice gate (Jensen et al. 1994). In addition to this source of nutrients for 'new production', nutrients were released from the sediment during the summer. We provide data for the seasonal variation in this internal loading from 3 sources: (1) In 1992 monthly measurements of sediment dissolved inorganic nitrogen (DIN) and dissolved inorganic phosphorus (DIP) release at 2 stations north and south of our sampling site (Fig. 1, Stations a and b) were performed by Jensen et al. (1994), (2) Measurements of sediment DIP release at the same 2 stations in 1995 were performed by Rasmussen (1996) except for the month of April, and finally (3) An estimate of sediment DIN release in 1995 was obtained from monthly measurements of the sediment release rate of total inorganic carbon (Rasmussen 1996) in combination with the $\mathrm{C}: \mathrm{N}$ ratio of seston.

Integrated water samples from the upper meter of the water column were collected for bioassays and nutrient analysis immediately before beginning the field bioassays. DIN and DIP were measured on Whatman GF/C-filtered samples, and total nitrogen (TN) and phosphorus (TP) on unfiltered samples (Grasshoff et al. 1983). The total content of carbon (TC), TN and TP in seston was measured on subsamples of particulate material collected on precombusted Whatman GF/C filters. The $\mathrm{C}$ and $\mathrm{N}$ content were measured using a CHN Elemental Analyzer EA1108 (Carlo Erba Instruments), and TP was measured by wet oxidation with potassium peroxydisulfate $\left(\mathrm{K}_{2} \mathrm{~S}_{2} \mathrm{O}_{8}\right)$ as described in Parsons et al. (1984). Data on dissolved silicate (DSi) concentrations were obtained from the County of Viborg (pers. comm.). Phytoplankton samples at the start of the incubation were preserved with Lugol's solution (Parsons et al. 1984), settled and enumerated by inverted microscopy to determine the relative species composition during each period.

Four different bioassays were carried out: a longterm bioassay and a dilution bioassay in the field (about $2 \mathrm{~d}$ ), and a short-term bioassay and a dilution bioassay in the laboratory ( $2 \mathrm{~h}$ ). All bioassays were carried out using an integrated sample from the upper meter of the water column. The bioassay treatments were addition of $\mathrm{N}\left(214 \mu \mathrm{M} \mathrm{NO}_{3}{ }^{-}\right), \mathrm{P}\left(19 \mu \mathrm{M} \mathrm{PO}_{4}{ }^{3-}\right)$, $\mathrm{N}+\mathrm{P}$ (same concentrations as when added alone), and finally controls without nutrient addition. Two replicates were made for each treatment. The additions of $\mathrm{N}$ and $\mathrm{P}$ were chosen so that concentrations were at least doubled compared to maximum concentrations measured in former years (County of Viborg pers. comm.). One-way ANOVA was used to test for differences among treatments and between treatments, and subsequently multiple comparisons were carried out using Tukey's test with a discrimination level of $\mathrm{p}<$ 0.05 .

Long-term bioassays were incubated in the field for about $18 \mathrm{~h}$ in $2.5 \mathrm{l}$ polycarbonate bottles placed horizontally in Perspex cylinders in a depth corresponding to half of the Secchi depth. In long-term dilution bioassays the estuary water was diluted 4 times with artificial seawater containing no $N$ or $P$. Artificial seawater was a mixture of Solutions 1 and $2+$ DSi according to Parsons et al. (1984). The artificial seawater was adjusted to the actual salinity and $\mathrm{pH}$ before mixing. The $2.5 \mathrm{l}$ bottles were shaken by hand every fifth hour during the incubation. The increase in chl a during incubation was used as a measure of biomass accumulation. Chl a was measured photometrically at $665 \mathrm{~nm}$ after extraction with $96 \%$ ethanol (Jespersen $\&$ Christoffersen 1987). The absorption at $480 \mathrm{~nm}$ was also measured on the extract to describe the carotenoid content (Strickland \& Parsons 1972). Absorption was corrected for turbidity measured at $750 \mathrm{~nm}$. At the end of the incubation, samples from all bottles were preserved with Lugol's solution (Parsons et al. 1984) for determination of algal species composition after incubation.

As for field bioassays, short-term laboratory bioassays were carried out both on undiluted water and on samples that were diluted 4 times with artificial seawater. Prior to the short-term incubation, a preincubation with nutrients took place for about $15 \mathrm{~h}$, as recommended by Nyholm \& Lyngby (1988). In this way the effect of the lag phase mentioned by Healey (1979), resulting from adaptation to the changed nutrient conditions, should be minimized. The preincubation was carried out in the dark, but according to Healey (1979), the nutrient-limited algae should have a high uptake of limiting nutrients both in the dark and in the light. Subsequently, short-term bioassays were carried out in the laboratory for $2 \mathrm{~h}$ in $20 \mathrm{ml}$ glass vials with addition of $100 \mu \mathrm{l} \mathrm{NaH}{ }^{14} \mathrm{CO}_{3}$ with an activity of $797 \mathrm{KBq} \mathrm{cm}^{-3}$ at in situ temperature and at a light intensity of $553 \mu \mathrm{E}$ $\mathrm{m}^{-2} \mathrm{~s}^{-1}$. Incorporated ${ }^{14} \mathrm{C}$ was used as an indicator of biomass growth. Excess ${ }^{14} \mathrm{C}$ was removed after incubation by addition of $1 \mathrm{~N} \mathrm{HCl}$, whereafter the samples were left open for $24 \mathrm{~h}$ (modification after Christof- 
fersen \& Riemann 1990) before adding scintillation liquid (Insta-Gel ${ }^{\otimes}$ ) and counting in a Liquid Scintillation Analyzer Model 1900 TR, PACKARD-Tri-Carb ${ }^{\otimes}$.

The exponential growth constant $(\mu)$ for phytoplankton was calculated for all bioassays as $\mu=\ln \left(N_{\mathrm{t}} / N_{0}\right) / t$, where $N_{\mathrm{t}}$ is the size of the phytoplankton population after the time $t$ (days), and $N_{0}$ is the initial population (Reynolds 1984). Growth rate calculations were based on changes in chl a concentration for long-term bioassays, and on calculated carbon uptake (measured by ${ }^{14} \mathrm{C}$ incorporation) relative to initial carbon content (measured by a CHN analyzer) in short-term bioassays.

\section{RESULTS}

The nutrient loading from various sources to the water body above the halocline in Hjarbæk Fjord is shown in Fig. 2. Most of the $\mathrm{N}$ loading came from the freshwater input, whereas the source of $P$ loading varied by season. In spring $P$ primarily came from the freshwater input, but during the summer most $P$ came from sediment release or was imported across the marine boundary. The resulting $\mathrm{N}$ : $\mathrm{P}$ ratio of the combined nutrient loadings was relatively high during most of the season, with a maximum at 112 and 294 in April and a minimum of 24 and 21 in August for TN:TP and DIN:DIP, respectively.

The concentrations of DIN and DIP in the surface water varied during the season (Fig. 3a). The highest value of DIN ( $215 \mu \mathrm{M})$ occurred in April. The concentration decreased gradually thereafter to a minimum in August $(\sim 2 \mu \mathrm{M})$ followed by a small rise in October.

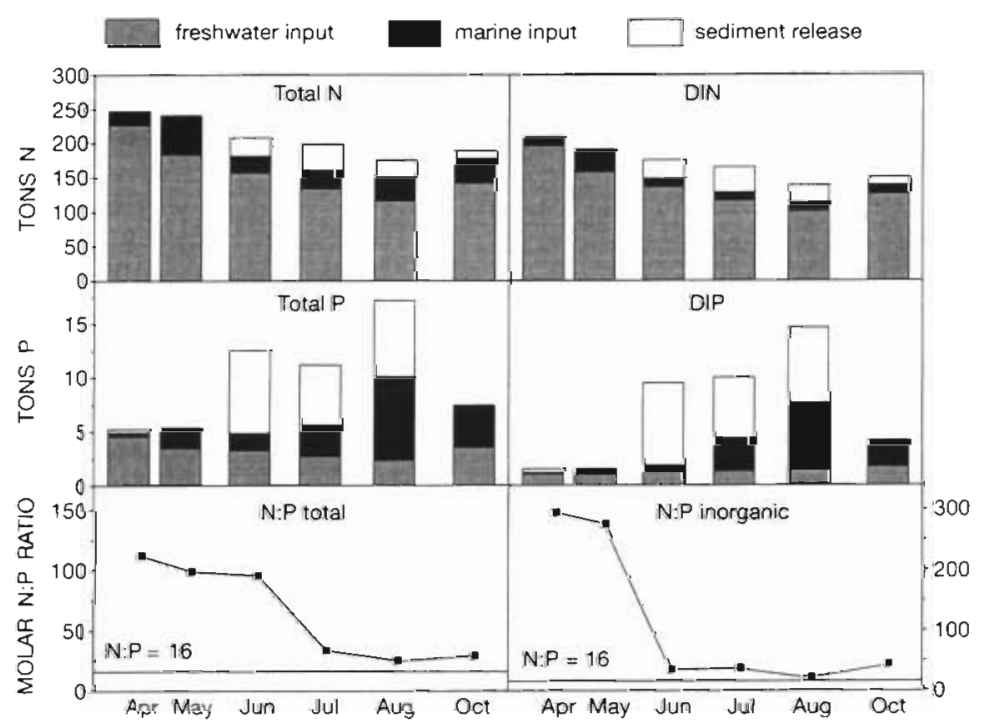

Fig. 2. Loading of inorganic (DIN and DIP) and total $N$ and $P$, and molar N:P ratios of the loadings to Hjarbæk Fjord during 1995

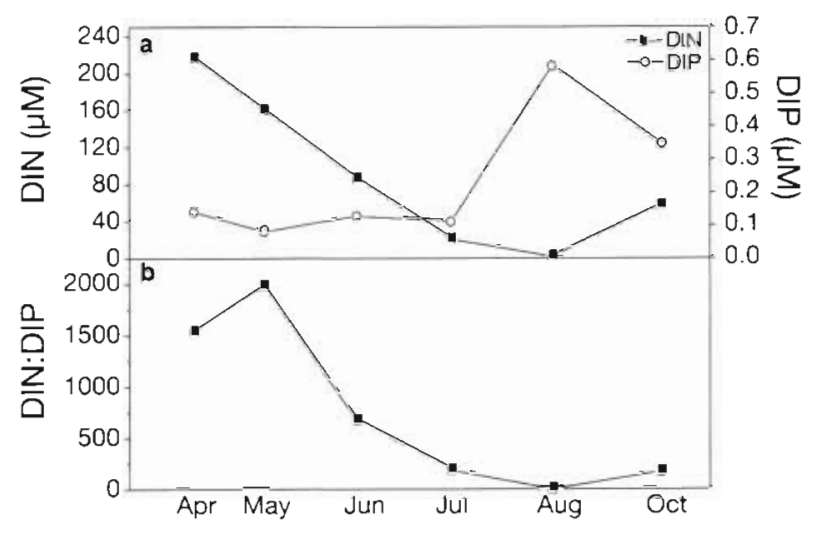

Fig. 3. Seasonal variation of (a) DIN and DIP concentrations and (b) DIN:DIP ratio in surface water of Hjarbak Fjord

The DIP concentration was very low from April to July $(\sim 0.1 \mu \mathrm{M})$, but in August and October higher concentrations prevailed ( $\sim 0.6$ and $\sim 0.35 \mu \mathrm{M}$, respectively). The resulting DIN:DIP ratio in the surface water (Fig. 3b) had a maximum of 2000 in May and a minimum of 3 in August. DSi concentration was $>25$ to $225 \mu \mathrm{M}$ during the experimental period, except in July where a minimum of about $4 \mu \mathrm{M}$ occurred. The C:N:P ratio in the particulate material (seston) showed a somewhat variable pattern (Fig. $4 \mathrm{a}, \mathrm{b}$ ). The C:N ratio in April of about 20 was very high compared to the other months, where it was between 8 and 11 . It should be noted that the weather in April was much more windy than in any of the other experimental periods and that resuspension of sediment and detritus occurred. The $C: P$ ratio was below 100 in April, and increased to around 210 in June-July, whereafter it fell gradually to about 100 in October. The N:P ratio was quite low, about 5 in April, but increased to about 20 in June-July, and finally decreased to slightly below 16 in October.

The seasonal variation in the phytoplankton community structure, surface water chl a and Secchi depth is given in Fig. 5. The phytoplankton population (Fig. 5a) in April and May was dominated by the diatoms Nitzschia spp. and Diatoma tenuis, respectively. In April and May cyanobacteria, primarily Oscillatoria planctonica and some unidentified more or less circular colonies (probably Microcystis sp. and Aphanothece sp.), were also present in large numbers, and these species dominated in June and July. Green algae were also present in June and July, primarily Scenedesmus spp. and especially Chlorella sp. The freshwater algae probably came from the inner part of the estuary. In August cyanobacteria dominated completely (O. planctonica, Merismopedia sp. and unidentified circular colonies). This was also true in 

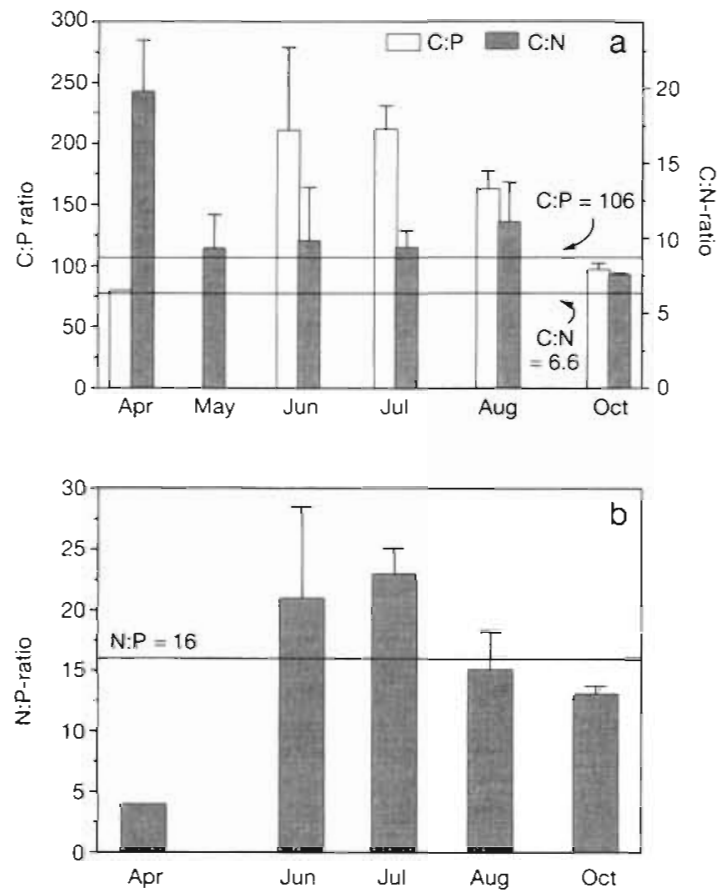

Fig. 4. (a) Molar C:N and C:P ratios and (b) molar N:P ratio in particulate material from surface water. No measurement of TP in May. Error bars indicate standard deviation

October although more green algae (e.g. Oocystis sp., Pediastrum cf. duplex, Scenedesmus spp.) and diatoms (primarily $D$. tenuis) were present. The Secchi depth (Fig. 5b) varied between 42 and $90 \mathrm{~cm}$, lowest in August, and the chl a concentration varied between 23 and $134 \mathrm{\mu g} \mathrm{l}^{-1}$, with minimum in May and maximum in October.

Field bioassays with undiluted seawater indicated no $\mathrm{N}$ or $\mathrm{P}$ limitation in April (Fig. 6a), whereas a significant indication of $\mathrm{P}$ limitation was found in May and June. In July only addition of both $\mathrm{N}$ and $\mathrm{P}$ resulted in a significantly increased growth. $\mathrm{N}$ limitation was significant in August, whereas minor $\mathrm{P}$ limitation occurred in October. In general only small differences are observed when field bioassays are compared to dilution bioassays (Fig. 6b). Most noteworthy is the complete difference in the August results, where dilution bioassay significantly indicates $P$ limitation. In July and October the indications of $\mathrm{P}$ limitation in dilution bioassay were not significant as in the bioassay.

In general there were only small changes in the relative composition of phytoplankton species during long-term bioassays (not shown). Only in August did we observe an increased number of diatoms after the incubation in the dilution bioassay. This change did not occur in ordinary long-term bioassay.

$P$ addition in the short-term laboratory bioassay, caused a similar positive effect on ${ }^{14} \mathrm{C}$ uptake rates in May, June and July (Fig. 7a) as was observed for field
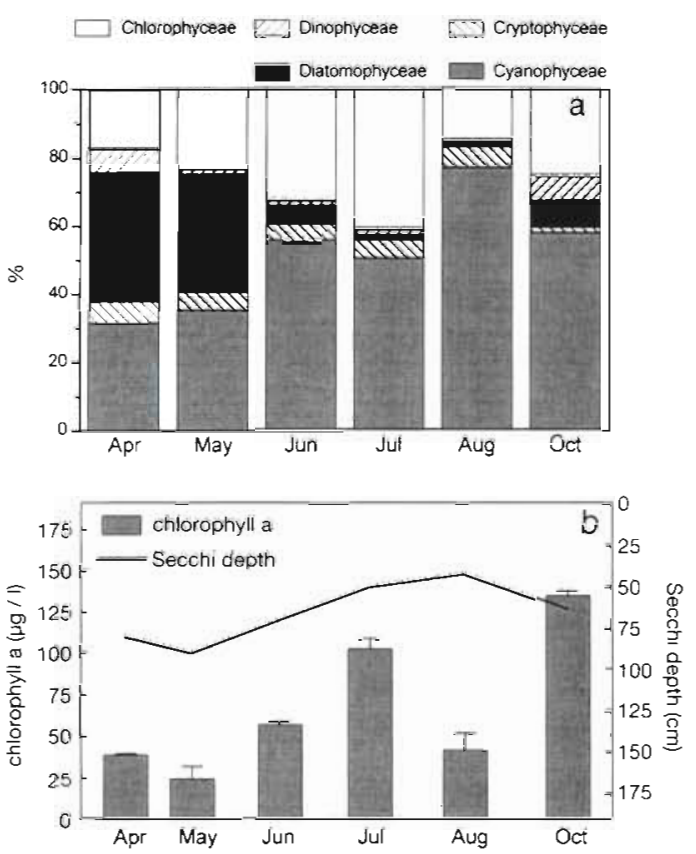

Fig. 5. (a) Seasonal variation in (a) the natural algae assemblage and (b) the chl $a$ and Secchi depth of Hjarbak. Fjord

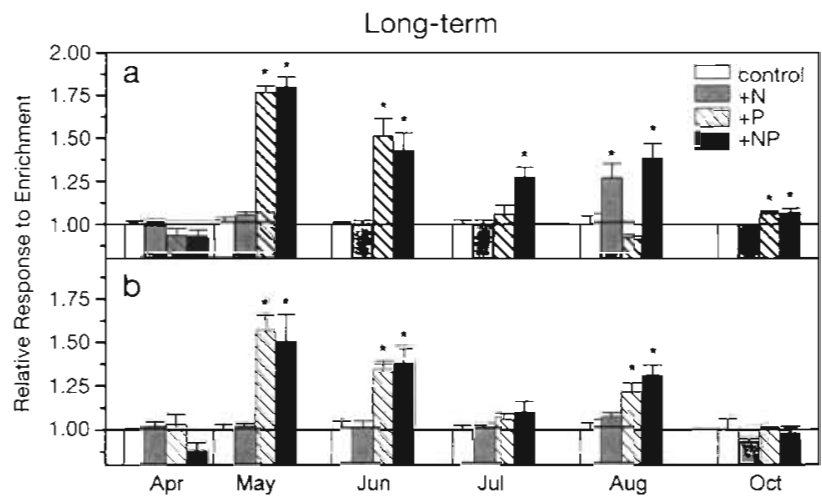

Fig. 6. (a) Bioassay and (b) dilution bioassay in long-term field experiments. Biomass increase (chl a increase) in response to enrichment with $\mathrm{N}, \mathrm{P}$ or $\mathrm{N}+\mathrm{P}$ relative to control. Error bars are standard error. "Significantly higher growth than control according to Tukey's test $(p<0.05)$

bioassays as measured by biomass accumulation. A similar tendency was also seen in August, though not significant. No $\mathrm{N}$ or P limitation was detectable in the short-term bioassay in April and October. Regarding the short-term dilution bioassay in the laboratory (Fig. 7b) the picture was somewhat blurred due to a high variation within each treatment.

The 480:665 ratio in the long-term bioassays decreased in May and June after addition of $\mathrm{P}$ and $\mathrm{N}+\mathrm{P}$ (Fig. 8a). No significant changes in the ratio occurred in April, July and October. In August the ratio de- 


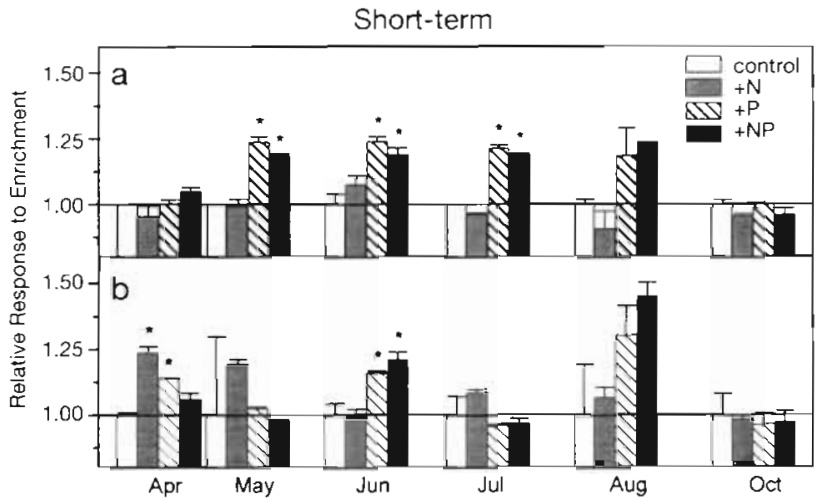

Fig. 7. (a) Bioassay and (b) dilution-bioassay in short-term laboratory experiments. Biomass increase $\left({ }^{14} \mathrm{C}\right.$ uptake $)$ in response to enrichment with $\mathrm{N}, \mathrm{P}$ or $\mathrm{N}+\mathrm{P}$ relative to control. Error bars are standard error. "Significantly higher growth than control according to Tukey's test $(p<0.05)$

creased after addition of $\mathrm{N}$ and $\mathrm{N}+\mathrm{P}$. In the dilution bioassay the 480:665 ratio decreased in May, June and August after addition of $\mathrm{P}$ and $\mathrm{N}+\mathrm{P}$ (Fig. 8b). No significant changes in the ratio occurred in April, July and October. There was a significant difference between the initial 480:665 ratio and the final 480:665 ratio in control bottles after incubation in all periods except in April. Initial 480:665 ratios were higher except in bioassays in August and October, and in the dilution bioassay in October where the controls were higher.

The exponential growth constant $(\mu)$ in the different bioassays (Table 1) was generally higher in short-term than in long-term bioassays, with rates varying between 0.01 and 1.12 . Occasionally $\mu$ was negative in the field dilution bioassay experiments.

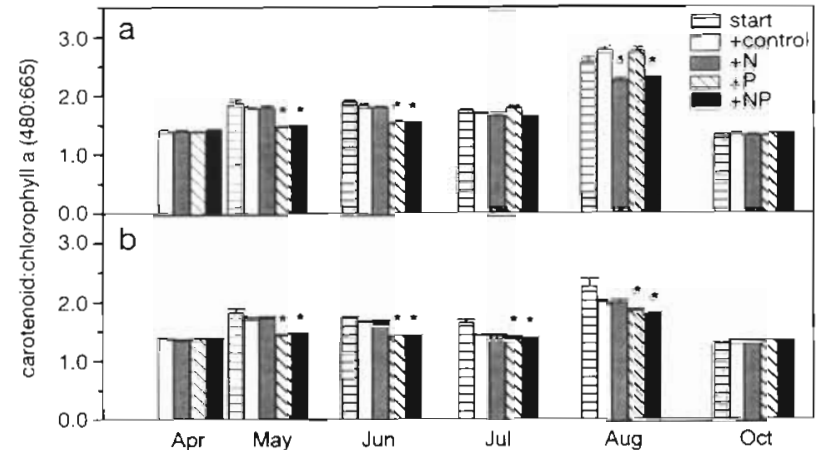

Fig. 8. Carotenoid:chl a ratio in (a) bioassay and (b) dilution bioassay. No start value was measured in April. Error bars are standard error. "Significantly lower ratio than control according to Tukey's test $(p<0.05)$

In Table 2 the results from all bioassay experiments are summarised. The assessment of the nutrient limitation as inferred from (1) nutrient loading ratios and concentrations of inorganic nutrients in water, and (2) seston C:N:P ratios was based on the following criteria regarding atomic ratios: (1) $\mathrm{N}$ limitation prevails if inorganic $\mathrm{N}: \mathrm{P} \leq 10$ and $\mathrm{P}$ limitation prevails if $\mathrm{N}: \mathrm{P} \geq 30$ (from Dortch \& Whitledge 1992) and (2) P limitation prevails if sestonic C:P $>106: 1$ and N limitation prevails if $\mathrm{C}: \mathrm{N}>6.6$ as for marine phytoplankton (Redfield et al. 1963). Nutrient limitation was evaluated from water column nutrient concentrations by comparing with half-saturation constants of uptake $\left(K_{\text {nutnent }}\right)$ for planktonic populations (Fisher et al. 1995). The observed inorganic nutrient levels were compared with $K_{\text {DIN }}=0.5-1.0 \mu \mathrm{M}\left(K_{\mathrm{NO}_{3} . \mathrm{NO}_{2}}\right.$ and $K_{\mathrm{NH}_{4}}$ are equal $)$ and $K_{\mathrm{PO}_{4}}=0.1-0.2 \mu \mathrm{M}$ to suggest possible limitation. Nutri-

Table 1. Exponential daily growth rates $\left[\mu=\ln \left(N_{t} / N_{0}\right) / t\right]$ for phytoplankton in bioassays

\begin{tabular}{|c|c|c|c|c|c|c|c|c|c|}
\hline \multicolumn{5}{|c|}{ Long-term experiments } & \multicolumn{5}{|c|}{ Short-term experiments } \\
\hline $\begin{array}{l}\text { Field } \\
\text { bioassay }\end{array}$ & Control & $+\mathrm{N}$ & $+\mathrm{P}$ & $+N P$ & $\begin{array}{l}\text { Laboratory } \\
\text { bioassay }\end{array}$ & Control & $+\mathrm{N}$ & $+\mathrm{P}$ & $+\mathrm{NP}$ \\
\hline Apr & 0.12 & 0.12 & 0.06 & 0.05 & Apr & 0.40 & 0.52 & 0.53 & 0.56 \\
\hline May & 0.06 & 0.01 & 0.31 & 0.32 & May & 0.16 & 0.20 & 0.25 & 0.24 \\
\hline Jun & 0.14 & 0.14 & 0.35 & 0.32 & Jun & 0.52 & 0.56 & 0.65 & 0.63 \\
\hline Jul & 0.05 & 0.05 & 0.08 & 0.18 & Jul & 0.55 & 0.68 & 0.83 & 0.86 \\
\hline Aug & 0.33 & 0.45 & 0.29 & 0.50 & Aug & 0.80 & 0.81 & 0.98 & 1.06 \\
\hline Oct & 0.10 & 0.10 & 0.14 & 0.14 & $\mathrm{Oct}$ & 0.49 & 0.47 & 0.49 & 0.48 \\
\hline \multicolumn{5}{|c|}{$\begin{array}{l}\text { Field } \\
\text { dilution bioassay }\end{array}$} & \multicolumn{5}{|c|}{$\begin{array}{l}\text { Laboratory } \\
\text { dilution bioassay }\end{array}$} \\
\hline Apr & 0.10 & 0.12 & 0.12 & -0.004 & Apr & 0.90 & 1.12 & 1.06 & 0.96 \\
\hline May & -0.18 & -0.17 & 0.07 & 0.05 & May & 0.08 & 0.10 & 0.09 & 0.08 \\
\hline Jun & -0.04 & -0.05 & 0.10 & 0.12 & Jun & 0.64 & 0.62 & 0.73 & 0.78 \\
\hline Jul & 0.08 & 0.08 & 0.11 & 0.13 & Jul & 0.56 & 0.56 & 0.47 & 0.49 \\
\hline Aug & 0.12 & 0.14 & 0.21 & 0.25 & Aug & 0.06 & 0.06 & 0.07 & 0.08 \\
\hline Oct & - & - & - & - & Oct & 0.23 & 0.23 & 0.22 & 0.23 \\
\hline
\end{tabular}


Table 2. Nutrient limitation in Hjarbæk Fjord, Denmark, 1995 according to different methods and criteria (see 'Results'). When limitation was not significant or when uncertain (but indicated) brackets are used. When no limitation was indicated it is specified as 'None'

\begin{tabular}{|c|c|c|c|c|c|c|}
\hline & \multicolumn{6}{|c|}{ Limitation } \\
\hline & Apr & May & Jun & Jul & Aug & Oct \\
\hline Inorganic nutrient loading ratios & $\mathrm{P}$ & $\mathrm{P}$ & $\mathrm{P}$ & $\mathrm{P}$ & None & $\mathrm{P}$ \\
\hline Water concentrations of inorganic nutrients & $\mathrm{P}$ & $\mathrm{P}$ & $\mathrm{P}$ & $\mathrm{P}$ & $\mathrm{N}$ & $\mathrm{P}$ \\
\hline Sestonic C:N:P ratio & $\mathrm{N}$ & - & (P) & (P) & None & $\mathrm{N}$ \\
\hline Long-term field bioassay & None & $\mathrm{P}$ & $\mathrm{P}$ & NP & $\mathrm{N}$ & $\mathrm{P}$ \\
\hline Long-term field dilution bioassay & None & $\mathrm{P}$ & $P$ & None & $\mathrm{P}$ & None \\
\hline Short-term laboratory bioassay & None & $\mathrm{P}$ & $\mathrm{P}$ & $\mathrm{P}$ & $(\mathrm{P})$ & None \\
\hline Short-term laboratory dilution bioassay & $\mathrm{N}$ & None & $\mathrm{P}$ & None & None & None \\
\hline Carotenoid:chlorophyll a ratio & None & $\mathrm{P}$ & $\mathrm{P}$ & None & $N$ & None \\
\hline Carotenoid:chlorophyll a ratio (dilution) & None & $\mathrm{P}$ & $\mathrm{P}$ & $P$ & $\mathrm{P}$ & None \\
\hline
\end{tabular}

ent limitation observed in bioassays, including carotenoid:chl a ratios, was evaluated from significant differences between treatments and controls following incubation.

\section{DISCUSSION}

A variety of bioassays and indicators have been applied in this study to examine which nutrient limited the phytoplankton primary production during the growth season. When all the methods used to determine nutrient limitation in the estuary were compared they generally provided similar results.

In April as well as in October neither $\mathrm{N}$ nor $\mathrm{P}$ was clearly limiting. In May and June all methods indicated $\mathrm{P}$ limitation, and also in July $\mathrm{P}$ limitation was indicated in most approaches. In August there were contradicting observation with the long-term field bioassay showing significantly different results from the other bioassays, both regarding $\mathrm{N}$ and $\mathrm{P}$ addition, whereas the other methods did not differ significantly. The concentration of nutrients in the water indicated $\mathrm{N}$ limitation in August, whereas nutrient loading and C:N:P ratio indicated no limitation because the N:P ratio was in between $\mathrm{N}$ and $\mathrm{P}$ limitation. Thus, it seems as if only the long-term field bioassay reflected the relatively low nitrogen concentration that was measured in August.

Indications of a seasonal switch between $\mathrm{N}$ and $\mathrm{P}$ limitation has been observed in other estuaries (D'Elia et al. 1986, Caraco 1988, Webb 1988, Fisher et al. 1992, Doering et al. 1995). This switch may be due to the seasonality in sediment $P$ release (Jensen et al. 1995, Conley 1999). Doering et al. (1995) found that this variation was caused by the N:P ratio in the external loading. The variation in the nutrient loading ratio was in accordance with the nutrient limitations found in most of the results from the bioassay experiments. Observations of nutrient limitation, based on the nutrient concentrations in the water column, also agreed with most of the results from the bioassays. However, an evaluation of which nutrient limits the phytoplankton primary production cannot solely be based on measurements of nutrient concentrations in the surrounding water, because nutrient storage in algae due to luxury uptake may occur (e.g. Dodds \& Priscu 1990). This is especially true for $\mathrm{P}$ (Reynolds 1984).

The C:N:P ratio in particulate material can be compared with the Redfield ratio (Redfield et al. 1963) to ascertain if nutrient limitation occurs. However, the $C: N: P$ ratio may vary in different algal groups, and the measurement of the ratio, which for practical reasons usually is made on seston, can be biased due to the influence of dead algae as well as non-algal material and can therefore be unreliable. Thus, in April where the water was very turbid because of high wind speed, resuspension may explain the high $C: N$ ratio as well as the low C:P and N:P ratios since surface sediments are often depleted in $\mathrm{N}$ and enriched in P. Low $\mathrm{C}: \mathrm{P}$ and $\mathrm{N}: \mathrm{P}$ ratios may also be due to luxury uptake of $P$.

Freshwater bioassay experiments regarding $\mathrm{P}$ and $\mathrm{N}$ limitation (reviewed by Elser et al. 1990) show relative growth responses to enrichment of 4.61 for $N+P, 1.97$ for $P$ and 1.79 for $N$ as average values, when measured as the ratio of the response variable in a treatment to the value in the control. Our relative growth responses were lower than these average values, which is probably due to the relatively eutrophic condition in Hjarbæk Fjord. Elser et al. (1990) found a significantly higher growth response when both $\mathrm{N}$ and $\mathrm{P}$ was added compared to single nutrient addition. In our experiments this response, indicating that both $\mathrm{N}$ and $\mathrm{P}$ are in relatively short supply, only occurred in field bioassay in July. This was due to the seasonal variation in nutrient regimes where $\mathrm{N}$ and $\mathrm{P}$ alternately were present in relatively high and low concentrations in Hjarbæk Fjord. Nutrient limitation was also examined in 
the nutrient-enriched Chesapeake Bay estuary (D'Elia et al. 1986) using bioassays with continuous cultures that were run in several weeks. Bioassays showed a large seasonal variation in the relative growth response (up to about 3 and 11 following addition of $P$ and $N$, respectively), but like in our experiment, relatively low ratios were observed during the first days. Thus, a larger relative growth response may have occurred in Hjarbæk Fjord if the duration of the experiment were longer (e.g. Vince \& Valiela 1973).

In the bioassays used in this study the growth rates were not always equal to maximum growth, because nutrients were often exploited to below the detection limit during the long-term incubations. In general, maximum growth rates vary between 0.21 and 2.9 divisions $d^{-1}$ in freshwater phytoplankton (Reynolds 1984), and between 0.1 and 5.9 divisions $\mathrm{d}^{-1}$ in marine phytoplankton (Furnas 1990). Our growth rates were generally low $\left(-0.2\right.$ to $\left.1.1 \mathrm{~d}^{-1}\right)$, which may be because we worked with mixed natural populations and not laboratory cultures, and also because the zooplankton were not removed prior to the experiments, so the apparent growth rate may have been reduced due to grazing. Furthermore, the growth conditions were not always optimal during our experiments. Higher growth rates were observed in short-term laboratory bioassays compared to long-term bioassays. This may be due to the optimal light conditions during laboratory bioassays, and, as discussed above, nutrients were more likely not to be depleted during short-term than during long-term bioassays, although a preincubation occurred in short-term bioassays. Growth rates obtained from short-term bioassays may actually be underestimates as they are based on the relation between ${ }^{14} \mathrm{C}$ incorporation and initial carbon content, the latter of which may be overestimated due to presence of detritus in the samples.

Dilution bioassays were not needed in the present study to assess nutrient limitation, because $\mathrm{N}$ and $\mathrm{P}$ concentrations were never as high at the same time that the limiting nutrient could not be identified with ordinary bioassays. Still dilution bioassay provides an example concerning what might happen if nutrient concentrations in Hjarbæk Fjord decreased with a reduction in both $\mathrm{N}$ and $\mathrm{P}$ loading. Thus, dilution bioassays indicated that $P$ would be limiting during most of the summer, including August. However, as dilution influences other factors than nutrient concentrations, care should be taken when evaluating the results. In some experimental periods the response to nutrient enrichment was significantly lower in long-term field dilution bioassays when compared with the long-term field bioassays. This was especially true in the cases of $P$ addition in the months where $P$ seemed limiting, and could possibly be due to a negative effect of the dilu- tion of other important substances (e.g. nutrients, micronutrients, vitamins) that are diluted and may limit growth, hence negative growth rates were observed in some cases. The short-term dilution bioassays in this study did not provide consistent results with the high variation observed in the control bioassays.

The most notable difference between bioassay and dilution bioassay was the contradicting results in August on whether $\mathrm{N}$ or $\mathrm{P}$ was limiting growth. In the dilution bioassay significant $\mathrm{P}$ limitation was observed, and there was a higher but not significant enhanced growth with $\mathrm{N}$ addition, and the growth in the combined $N+P$ addition was significantly higher than the $P$ addition alone, indicating secondary limitation of $\mathrm{N}$. A similar change from $\mathrm{N}$ to $\mathrm{P}$ limitation following dilution was observed by Carrick et al. (1993) at dilutions of $30 \%$ and more. The change could possibly be due to the effect of allelopathic substances. The plankton community in August was entirely dominated by cyanobacteria, which may secrete allelopathic substances that inhibit growth of other algae, in particular diatoms (Keating 1978). The presence of increased numbers of diatoms in all bottles from dilution bioassay after incubation in August, and the fact that the same change in the algae population did not occur in the ordinary bioassay, supports this hypothesis. According to measurements made by the County of Viborg (authors' pers. comm.), the DSi was relatively high (about $150 \mu \mathrm{M}$ ) in August, so no effect would be expected from addition of artificial seawater containing DSi. According to Egge \& Aksnes (1992) diatoms can dominate as long as the silicate concentrations are above $2 \mu \mathrm{M}$. As the lowest Dsi concentration was $4 \mu \mathrm{M}$ in July (also lowest relative abundance of diatoms), no DSi limitation seems to occur.

During the $2 \mathrm{~d}$ of long-term incubation, some changes in the species composition may occur as previously stated. Therefore, we consider the long-term bioassays to measure the potential limitation of this 'new' population, and its ability to transform the added nutrients into growth, while the short-term bioassay, using $\mathrm{H}^{14} \mathrm{CO}_{3}^{-}$-incubation as an indicator of growth, likely provides better information of which nutrient actually limits the growth of the natural algae population. Minor changes might have taken place during the $15 \mathrm{~h}$ preincubation which could affect the term 'shortterm' bioassay results, although the results obtained by long-term and short-term bioassays agreed well. However, different results were obtained in August, where the ${ }^{14} \mathrm{C}$ incubation indicates a tendency of $\mathrm{P}$ limitation. Explanation of this difference could be found in the use of different indicators of growth. Paerl \& Bowles (1987) found using bioassays, that in a case of $\mathrm{N}$ limitation, $\mathrm{N}$ addition resulted in a chl a increase, but not in an 
increased ${ }^{14} \mathrm{C}$ uptake. In other cases they found indications of $\mathrm{N}$ limitation from both indicators, though still most clearly with chl a as an indicator. Compared with ${ }^{14} \mathrm{C}$ incorporation in August the apparent $\mathrm{N}$ limitation found according to the changes in chl a could therefore be overestimated.

No cyanobacteria with heterocysts were observed in August, but still $\mathrm{N}$ fixation could have occurred, as some non-heterocystous species have been found capable of $\mathrm{N}$ fixation (Griffiths et al. 1987, Anand \& Murugesan 1996). Some cyanobacteria are capable of $N$ storage (Carr 1988), which leads to the possibility that these reserves were sufficient to cover the needs during short-term incubation, but not during long-term incubation. Meanwhile, the concentration of DIP was quite high in August (also after a long-term incubation), and also the N:P loading ratio indicated a possibility for $\mathrm{N}$ limitation.

The 480:665 ratio depends on other factors than just nutrient limitation. The ratio may vary with the seasonal occurrence of phytoplankton species (Margalef 1968), because different algal groups have different ratios (Heath et al. 1990). In the present study we observed small but significant differences between start and control ratios which may be caused by minor changes in the algae assemblage during incubation. Watson \& Osborne (1979) found the highest 480:665 ratios $(>2.4)$ in cases of extreme $\mathrm{N}$ limitation, and ratios of 1.4 to 2.4 and $<1.4$ at moderate or no $\mathrm{N}$ limitation, respectively. In contrast Schlüter et al. (1997) found the highest values in nutrient-replete cells, and proposed that this may be due to light adaptation in their experiment, causing decreased amounts of chlorophyll and increased synthesis of carotenoids. They also observed a decrease in the $480: 665$ ratio when nutrients were added in cases with potential nutrient limitation. Our results are in accordance with Watson \& Osborne (1979) since we observed a high 480:665 ratio (about 2.6) when $N$ limitation was indicated in August by long-term bioassay, and the lowest values (about 1.4) in April and October when no or only little nutrient limitation was indicated. Still, the start values in the 480:665 ratio were high (1.7 to 1.9 ) in May-July where $P$ limitation was indicated in most bioassays. The observation that the 480:665 ratio decreased during long-term incubation in August agrees with results found by Heath et al. (1990) in long-term bioassays concerning indications of $N$ limitation, but the $480: 665$ ratio also decreased when $P$ was added and $P$ limitation was significant according to bioassay. Thus, a high 480:665 ratio is not necessarily an indication of $N$ limitation, but a decrease in the ratio seems to be useful as a general indicator of $\mathrm{N}$ and/or $\mathrm{P}$ limitation. According to the present study, the ratio is not specific for $\mathrm{N}$ limitation alone. Since the ratio may vary with the com- position of dominant species, it must be supplemented with other indicators or analysis, for instance bioassay experiments.

This study provided a case of an estuary being $P$ limited during most of the season. It also provided a case of an estuary, where $\mathrm{N}$ versus $\mathrm{P}$ limitation as verified by the various bioassays, corresponded well with the limitation predicted from the seasonal changes in the nutrient loading ratios and surface water nutrient concentrations. However, this may not always be the case (Fisher et al. 1995), and in such situations, and in cases where nutrient loading data are difficult to obtain, bioassays may be a valuable tool and an indicator of phytoplankton nutrient limitation.

Acknowledgements. We thank Gudrun Krog, County of Viborg, for providing data for the mass balance calculations, and Daniel Conley for comments on the manuscript. This study was partly supported by grant no. 9601423 from the Danish Natural Science Research Council.

\section{LITERATURE CITED}

Anand N, Murugesan VSR (1996) Nitrogen fixation at night in nature. Curr Sci 70:119-120

Caraco NF (1988) What is the mechanism behind the seasonal switch between $N$ and P limitation in estuaries? Can J Fish Aquat Sci 45:381-382

Caraco NF, Cole JJ, Likens GE (1990) A comparison of phosphorus immobilization in sediments of freshwater and coastal marine systems. Biogeochemistry 9:277-290

Carr NG (1988) Nitrogen reserves and dynamic reservoirs in cyanobacteria. In: Rogers LJ, Gallon JR (eds) Biochemistry of the algae and cyanobacteria-proceedings of the phytochemical society of Europe. Oxford University Press, New York, p 13-21

Carrick HJ, Schelske CL, Aldridge FJ (1993) Assessment of phytoplankton nutrient limitation in productive waters: application of dilution bioassays. Can J Fish Aquat Sci 50: $2208-2221$

Christoffersen K, Riemann B (1990) Alternativ metode til bestemmelse af planktonalgers primærproduktion. Vand \& Miljø 1:12-14

Conley DJ (1999) Biogeochemical nutrient cycles and nutrient management strategies. Hydrobiologia (in press)

D'Elia CF, Sanders JG, Boynton WR (1986) Nutrient enrichment studies in a coastal plain estuary: phytoplankton growth in large-scale, continuous cultures. Can J Fish Aquat Sci 43:397-406

Dodds WK, Priscu JC (1990) A comparison of methods for assessment of nutrient defiency of phytoplankton in a large oligotrophic lake. Can J Fish Aquat Sci 47: $2328-2338$

Doering PH, Oviatt CA, Nowicki BL, Klos EG, Reed LW (1995) Phosphorus and nitrogen limitation of primary production in a simulated estuarine gradient. Mar Ecol Prog Ser 124: $271-287$

Dortch Q, Whitledge TE (1992) Does nitrogen or silicon limit phytoplankton production in the Mississippi River plume and nearby regions? Cont Shelf Res 12:1293-1309

Egge JK, Aksnes DL (1992) Silicate as regulating nutrient in phytoplankton competition. Mar Ecol Prog Ser 83:281-289 
Elser JJ, Marzolf ER, Goldman CR (1990) Phosphorus and nitrogen limitation of phytoplankton growth in the freshwaters of North America: a review and critique of experimental enrichments. Can J Fish Aquat Sci 47:1468-1477

Fisher TR, Peele ER, Harding LWJ Jr (1992) Nutrient limitation of phytoplankton in Chesapeake bay. Mar Ecol Prog Ser 82:51-63

Fisher TR, Melack JM, Grobbelaar JU, Howarth RW (1995) Nutrient limitation of phytoplankton and eutrophication of inland, estuarine, and marine waters. In: Tiessen $\mathrm{H}$ (ed) Phosphorus in the global environment. John Wiley \& Sons Ltd, Chichester, p 301-322

Furnas MJ (1990) In situ growth rates of marine phytoplankton: approaches to measurement, community and species growth rates. J Plankton Res 12(6):1117-1151

Granéli E, Granéli W, Rydberg L (1986) Nutrient limitation at the ecosystem and the phytoplankton community level in the Laholm Bay, south-east Kattegat. Ophelia 26:181-194

Griffiths MSH, Gallon JR, Chaplin AE (1987) The diurnal pattern of dinitrogen fixation by cyanobacteria in situ. New Phytol 107:649-657

Healey FP (1979) Short-term responses of nutrient-deficient algae to nutrient addition. J Phycol 15:289-299

Heath MR, Richardson K, Kiørboe T (1990) Optical assessment of phytoplankton nutrient depletion. J Plankton Res 12:381-396

Hecky RE, Kilham P (1988) Nutrient limitation of phytoplankton in freshwater and marine environments: a review of recent evidence on the effects of enrichment. Limnol Oceanogr 33:796-822

Howarth RW (1988) Nutrient limitation of net primary production in marine ecosystems. Annu Rev Ecol 19:89-110

Jensen HS, Sampou PA, Holmer M (1994) 'Næringssaltudveksling mellem sediment og vand i Hjarbæk Fjord efter etablering af saltvandstilstand i 1991.' (Nutrient exchange between water and sediment in Hjarbak Fjord after change from freshwater to saltwater conditions.) DMU report No. 107 Ministry of Environment, Silkeborg

Jensen HS, Mortensen PB, Andersen F $\varnothing$, Rasmussen $E$, Jensen A (1995) Phosphorus cycling in a coastal marine sediment, Aarhus Bay, Denmark. Limnol Oceanogr 40(5): 908-917

Jespersen A, Christoffersen K (1987) Measurements of chlorophyll-a from phytoplankton using ethanol as extraction solvent. Arch Hydrobiol 109:445-454

Keating KI (1978) Blue-green algal inhibition of diatom growth: transition from mesotrophic to eutrophic community structure. Science 199:971-973

Koroleff F (1983) Determination of nutrients. In: Grasshoff $M$, Ehrhardt $M$, Kremling $\mathrm{K}$ (eds) Methods of seawater

Editorial responsibility: Otto Kinne (Editor), Oldendorf/Luhe, Germany analysis, 2nd edn. Verlag Chemie, Weinheim, p 125-187

Maestrini SY, Bonin DJ, Droop MR (1984) Phytoplankton as indicators of sea water quality: bioassay approaches and protocols. In: Schubert LE (ed) Algae as ecological indicators. Academic Press Inc, London, p 71-132

Margalef DR (1968) Perspectives in ecological theory. University of Chicago Press, Chicago

Nixon SW, Ammenman JW, Atkinson LP, Berounsky VM, Billen $G$, Boicourt WC, Boynton WR, Church TM, DiToro DM, Elmgren R, Garber JH, Giblin AE, Jahnke RA, Owens NJP, Pilson MEQ, Seitzinger SP (1996) The fate of nitrogen and phosphor at the land-sea margin of the North Atlantic Ocean. Biogeochemistry 35:141-180

Nyholm N, Lyngby JE (1988) Algal bioassays in eutrophication research - a discussion in the framework of a mathematical analysis. Wat Res 22:1293-1300

Paerl HW, Bowles D (1987) Dilution bioassays: their application to assessments of nutrient limitation in hypereutrophic waters. Hydrobiologia 146:265-273

Parsons TR, Maita Y, Lalli CM (1984) A manual of chemical and biological methods for seawater analysis. Pergamon Press, Oxford

Rasmussen ND (1996) 'Sulfatreduktionens indflydelse på den interne fosforbelastning i Hjarbæek Fjord' (The influence of sulfate reduction on the internal phosphorus load in Hjarbæk Fjord.) Master thesis, University of Odense

Redfield AC, Ketchum BH, Richards FA (1963) The influence of organisms on the composition of sea-water. In: Hill MN (ed) The sea. Wiley Interscience, New York, p 26-79

Reynolds CS (1984) The ecology of freshwater phytoplankton. Cambridge University Press, Cambridge

Schelske CL (1984) In situ and natural phytoplankton assemblage bioassays. In: Schubert LE (ed) Algae as ecological indicators. Academic Press Inc, London, p 15-47

Schlüter L, Riemann B, Sondergaard M (1997) Nutrient limitation in relation to phytoplankton carotenoid/chl a ratios in freshwater mesocosms. J Plankton Res 19:891-906

Strickland JDH, Parsons TR (1972) A practical handbook of seawater analysis. Bull Fish Res Board Can 167

Vince S, Valiela I (1973) The effects of ammonium and phosphate enrichments on chlorophyll $a_{1}$ pigment ratio and species composition of phytoplankton of Vineyard Sound. Mar Biol 19:69-73

Watson RA, Osborne PL (1979) An algal pigment ratio as an indicator of the nitrogen supply to phytoplankton in three Norfolk broads. Freshw Biol 9:585-594

Webb KL (1988) Comment on 'Nutrient limitation of phytoplankton growth in brackish coastal ponds' by Caraco, Tamse, Boutros, and Valiela (1987). Can J Fish Aquat Sci $45: 380-381$

Submitted: May 11, 1998; Accepted: May 7, 1999

Proofs received from author(s): September 8, 1999 